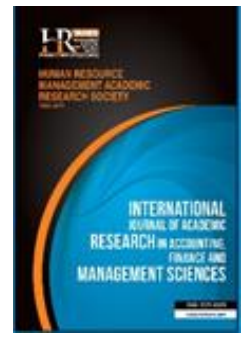

International Journal of Academic Research in Accounting, Finance and Management Sciences

Vol. 8, No.2, April 2018, pp. 235-249

E-ISSN: 2225-8329, P-ISSN: 2308-0337

(c) 2018 HRMARS

www.hrmars.com

To cite this article: Pernamasari, R. (2018). Implementation of Good Corporate Governance and Voluntary Disclosure Compliance: 100 Compass Index Companies Listed Indonesian Stock Exhange (IDX) 2015-2016, International Journal of Academic Research in Accounting, Finance and Management Sciences 8 (2): 235-249.

\title{
Implementation of Good Corporate Governance and Voluntary Disclosure Compliance: 100 Compass Index Companies Listed Indonesian Stock Exchange (IDX) 2015-2016
}

\author{
Rieke PERNAMASARI \\ Accounting Program, Economics and Business Faculty, , Mercu Buana University - Meruya Selatan no. 1, West Jakarta, \\ 11650, Indonesia, Email: rieke.pernamasari@mercubuana.ac.id
}

\begin{abstract}
The purpose of this study is to discuss the role of the company's 100 compass indexed in developing the best practices of corporate governance on voluntary disclosure. Based on the annual financial statements of 70 companies listed on the Indonesia Stock Exchange (IDX) for 2015-2016, the results show that the average voluntary disclosure in the company's annual report of 100 to 2015 composite protected futures is $76.73 \%$. This value indicates that the company indexed 100 compasses on average can meet 21 items of 28 voluntary disclosure items. The percentage of unsatisfactory disclosure implies that there are several factors that may prevent the company from disclosing some sensitive information. The results of the study show that institutional ownership has a positive effect on voluntary disclosure, while for the proportion of boards of commissioners with accounting or business skills, and the proportion of audit committees with accounting or business skills has a significant negative effect on voluntary disclosure and other variables, ie the proportion of independent board of commissioners, meetings of the board of commissioners, the frequency of audit committee meetings and the proportion of independent audit committees have no effect on voluntary disclosure.
\end{abstract}

Key words Good corporate governance, agency theory, voluntary disclosure

$\begin{array}{ccc}\text { Received: } & 18 \text { Jun } 2018 \quad \text { C The Authors } 2018 \\ \text { Revised: } & 08 \text { Jul } 2018 \quad \text { Published by Human Resource Management Academic Research Society (www.hrmars.com) }\end{array}$

Accepted: $15 \mathrm{Jul} 2018$ This article is published under the Creative Commons Attribution (CC BY 4.0) license. Anyone may Published Online: $25 \mathrm{Jul} 2018$ reproduce, distribute, translate and create derivative works of this article (for both commercial and noncommercial purposes), subject to full attribution to the original publication and authors. The full terms of this license may be seen at: http://creativecommons.org/licences/by/4.0/legalcode

\section{Introduction}

In the current era of openness, companies are required to manage corporate entities accountably and transparently. One form of accountability and transparency is to apply Good Corporate Governance (GCG). The implementation of GCG is expected to improve management oversight to encourage companies to make decisions, prevent opportunistic actions that are inconsistent with corporate interests, and reduce information asymmetry between management and corporate stakeholders.

Khan (2012) revealed that after several major companies collapsed, business scandals continued and issues of protection against minority shareholders so voluntary disclosure at the company received much attention in recent times. Gantyowati (2014) stated when companies have good news, companies will do more disclosure to attract investors, but when companies are experiencing financial distress, companies will tend to disclose limited information. This means that the company will disclose less information when the company experiences a financial distress. Yaseen (2013) said the threat of business failure and bankruptcy to companies is pressuring corporate governance committees and organizations around the 
world to provide information in a number of reports and establish rules that can assist in the monitoring and oversight of the company's management system. Fawzi (2014) on his result corporate governance mechanism and voluntary disclosure compliance: the case of bank in Jordan. After computing the voluntary disclosure index, the results show that the average disclosure score is $61.3 \%$, which is unsatisfactory. Apart from employee information, the results show high consistency in disclosure practices among Jordanian banks. The unsatisfactory percentage of disclosure implies that there are several factors may hinder banks from disclosing some sensitive information. The findings of the study have many applications for decision makers in Jordan and other developing countries.

According to Darrough (1993) in Ula (2015) voluntary disclosure is a free disclosure of company management to provide accounting information and other information deemed relevant for decision making of annual reports. In realizing voluntary disclosures that are adequate for the benefit of shareholders and the company, the management role is very important because voluntary disclosure in the annual report is disclosed by the company's accountant with the approval of the top management of the company. If a company has a good corporate governance system, then the quality of the company's voluntary disclosure will be better.

Until recently, empirical evidence that entered into the voluntary disclosure level on the stock market was limited and focused on capital market development. Haddad (2009) in his research on the relationship between the level of disclosure and stock market liquidity in the case of Arab financial market (ASE case), resulted in that there is considerable variation in this voluntary disclosure among companies. On average, a company discloses $28 \%$ of the information items included in the disclosure index whose disclosure environment is low, but the regression results show that the higher voluntary disclosed information provided in Jordan's annual report will increase the stock market liquidity. Craig and Diga (1998) in Wiwik (2006) analyzed disclosure practices in the annual report on public companies covering five ASEAN countries: (1) Malaysia, (2) Indonesia, (3) Philippines, (4) Thailand and (5) Singapore. The results show that Indonesia is a country that provides the least disclosure, and the role of the accounting profession in managing the disclosure of financial statements is also the least.

This study focuses on examining the effects of a set of Corporate Governance mechanisms that include the proportion of independent board of commissioners, institutional ownership, the proportion of boards of commissioners with accounting or business skills, the proportion of audit committees with accounting or business skills, the number of board meetings, , and the proportion of independent audit committees to voluntary disclosure in 100 compass index companies listed 2015 - 2016.

\subsection{Problem Research Formulation}

The problem in this research is 1 ) are the proportion of Independent Commissioner affect the voluntary disclosure? 2) Does institutional ownership affect voluntary disclosure? 3) Are the proportion of the board of commissioners with accounting or business skills affects the voluntary disclosure? 4) Are the proportion of audit committees with accounting or business skills affects the voluntary disclosure? 5) Does the frequency of board of commissioners' meetings affect voluntary disclosure? 6) Does the frequency of Audit Committee meetings affect voluntary disclosure? And 7) are proportion of independent audit committee influences voluntary disclosure?

\section{Literature review}

\subsection{Agency theory}

Jensen and Meckling (1976) in agency theory describe shareholders as principal and management as agents. Management is a party contracted by shareholders to work in the interests of shareholders, therefore management is given some power to make decisions for the best interests of shareholders.

Banhart and Rosenstein (1998) at Godeliva (2015) divided the corporate governance mechanisms into two groups. First, an internal mechanism to control the company using structures and processes such as board structure, and managerial ownership. Second, external mechanisms are a way of influencing companies in addition to internal mechanisms, such as markets for corporate control, institutional ownership and debt financing levels. There are two points emphasized in the corporate goverance mechanism, firstly, the importance of the right of shareholders or investors to obtain timely and accurate 
information, and secondly, the company's obligation to accurately, timely and transparently disclose all company performance information, ownership and stakeholders.

Based on agency theory that the proportion of independent board of commissioners, the proportion of boards of commissioners with accounting or business capacity, the number of board meetings, and institutional ownership can reflect the degree of independence, ability and quality of the management of the company. While the proportion of independent audit committees, the proportion of auditing committees with accounting or business skills, and the number of audit committee meetings may reflect the quality level of disclosures in the financial statements.

The signal theory brings about a new question: even if the disclosed information would be shared by all, it is nevertheless not necessarily perceived by all in the same way.

\subsection{Voluntary Disclosure}

Voluntary disclosure is a voluntary disclosure by a company without being required by applicable regulations. Meek Et al (1995) in Godeliva (2015) states voluntary disclosure is the disclosure of information beyond the required because it is deemed relevant to the needs of the users of the financial statements. One way to increase the company's credibility is through voluntary disclosure more broadly and assists investors in understanding business management strategies. research:

Verrechia (2001) on Heger dan Hubert (2010) research, proposed to identify three avenues of

a. The first field of research is constituted by works which the main objective is to analyze the consequences of disclosure on investors' behavior and more precisely through the reactions of stock prices and trading volumes. This first field of research is called "association-based disclosure". More specifically, studies enrolling in this line of research have focused on two specific relationships: the relationship between the publication of information and changes in stock prices and the relationship between the publication of information and changes volumes of shares traded.

b. "The discretionary-based disclosure approach "identifies studies suggesting that if the managers' objective is maximizing the market value of the firm and that there are costs of publishing information, then there is a balance in which information which is reflected by an increase in market value of the firm is released.

c. The third and final line of research revealed by Verrechia includes work on the study of disclosure categories which are preferred in the absence of an informational previous knowledge. This third line of research is called "efficiency-based disclosure. More specifically, work on the efficiency-based disclosure focused on a possible link between disclosure and information asymmetry reduction. Diamond and Verrechia (1991) and Kim and Verrechia (1994), state that voluntary disclosure reduces information asymmetries between the informed investors and the uninformed ones.

\section{Conceptual and hypotheses development}

\subsection{The Effect of Proportion of Independent Commissioners on Voluntary Disclosure}

Based on agency theory independent board of commissioners will have greater power in monitoring management to disclose information or voluntary disclosure. The existence of independent board members is also expected to increase the transparency of the company and reduce the information asymmetry among the company's owners and managers. Gantyowati (2014) and Akhtaruddin et al. (2009) in his research obtained independent commissioners have a positive influence on the level of voluntary disclosure presented by the company.

H1: The proportion of the Board of Independent Commissioners has a positive effect on Voluntary Disclosure.

\subsection{The effect of institutional ownership on Voluntary Disclosure}

Institutional ownership is a form of ownership of shares of a company owned by one or more institutions (institutions). Institutions or institutions here can be a bank, investment company, or other company. The existence of ownership by institutions (institutions) will encourage more effective and 
efficient supervision of the company's performance. Based on the agency theory if institutional ownership that has a greater proportion of shares will be able to urge managers and directors to disclose both mandatory disclosure and voluntary disclosure. The Ula (2015) study shows the effect of institutional ownership on voluntary disclosure.

H2: institutional ownership positively affects Voluntary Disclosure.

\subsection{The effect of the proportion of boards of commissioners who have accounting or business skills on voluntary disclosure}

GCG Indonesia 2006 guidance on the capacity and integrity of the members of the board of commissioners stating that members of the board of commissioners must have a condition of ability and integrity so that the implementation of supervisory and advisory functions for the interests of the company can be implemented properly. Therefore, more proportion of board of commissioners who have the ability to account or business higher the level of corporate voluntary disclosure. The Nuryaman (2010) study on Ula (2015) resulted in the proportion of boards of commissioners with accounting or business skills have positive effect to voluntary disclosure.

H3: the proportion of boards of commissioners with accounting or business skills positively effects to voluntary disclosure.

\subsection{The effect of the proportion of audit committees that have accounting or business skills on voluntary disclosure}

The audit committee will work more effectively if the proportion of audit committee members has expertise in accounting, auditing, internal control and finance. The resulting effectiveness is the increased level of corporate compliance with applicable regulations and recommendations on the most appropriate accounting policies with the company, which of course will cause the company to disclose additional information in the annual report as an explanation of the new policy undertaken by the company. Othman et al. (2014) states that financial problems will rarely occur if the company has audit committee members who are experts in finance, so companies will disclose more information. Ayu Research (2013) results in the proportion of audit committees with accounting or business skills positively effect to voluntary disclosure.

H4: the proportion of auditing committees with accounting or business accounting positively effects voluntary disclosure.

\subsection{The effect of the frequency of board meetings on voluntary disclosure}

FCGI (2001) explains that the board of commissioners meeting is a communication and coordination medium among management. At meetings conducted by the board of commissioners, the performance of the management will be evaluated and the board of commissioners will provide feedback regarding the implementation of the tasks that have been carried out by the management. Meeting activities will also address issues regarding the direction and strategy of the company, the policy evaluation that has been taken or carried out by the management, and solving problem the conflict of interest issues. Gantyowati (2014) in his research said the regular meeting held by the board of commissioners will also evaluate the policies taken by management and solving the occurrence of conflicts of interest between shareholders and managers

\section{H5: the frequency of board meetings has a positive effect on voluntary disclosure}

\subsection{The effect on the frequency of audit committee meetings on voluntary disclosure}

The requirements of Bapepam-LK (2012) in the Decree of the Chairman of the Capital Market and Financial Institution Supervisory Agency Number: KEP643/BL/2012 states that audit committee meetings are at least equal to the minimum requirement of board of commissioners meeting stipulated in the articles of association. In carrying out its duties and responsibilities to the board of commissioners, audit committee meetings are expected to increase the level of coordination, supervision and control levels and impact on increasing levels of disclosure made by the company. The more frequent meetings the better the level of supervision, so that the company is able to reduce agency costs that occur through increased 
transparency and disclosure of the company. Ayu Research (2013) resulted in audit committee meetings have a positive effect on voluntary disclosure.

H6: The frequency of audit committee meetings has a positive effect on voluntary disclosure.

\subsection{The effect of Proportion of Independent Audit Committee on Voluntary Disclosure}

NACD (2000) states that the audit committee has an important role in ensuring the quality of financial reporting, reviewing and assessing the internal control system and monitoring the relationship between management and external auditors. Othman et al. (2014) states that the existence of independent audit committee members can reduce the occurrence of fraud by management in the financial statements. One of the main tasks of the audit committee is to ensure that the information presented by the management is reliable and free from misstatement. Ayu (2013) and Ho and Wang (2001) in his research found a positive relationship between an independent audit committee with voluntary disclosure.

H7: independent audit committee positively effects voluntary disclosure.

\section{Methodology of research}

\subsection{Research Design}

This study uses hypothesis testing which aims to examine the effect of variables on the proportion of Independent Commissioners (X1), institutional ownership (X2), the proportion of boards of commissioners with accounting or business skills (X3), the proportion of audit committees with accounting or business skills (X4) frequency of meetings of independent commissioners (X5), frequency of audit committee meetings (X6), Audit Committee (X7) and Voluntary Disclosure (Y). This type of research is causality study. The analytical unit is 100 compass index company listed on the Indonesia Stock Exchange (IDX) in the form of corporate financial report data 2015-2016 while the time horizon used is panel studies is a combination of time series and cross-section.

\subsection{Data Collection Techniques}

The data used in this study is secondary data obtained from electronic media derived from annual financial statements of companies during the period 2015-2016, which can be accessed directly through the Indonesia Stock Exchange site (www.idx.go.id) or their respective sites company sample research. Other supporting resources are needed journals and other sources that can be used in this research.

\subsection{Population and Sample Research}

The research population is a 100 compass indexed company listed on the Indonesia Stock Exchange with a research period of two years from 2015 to 2016.

Table 1. Sample selection process

\begin{tabular}{|l|r|}
\hline \multicolumn{1}{|c|}{ Information } & Total \\
\hline The Companie's 100 compass indexes, years 2015- 2016: $100 \times 2$ yr period & 200 data \\
\hline The company's 100 compass indexes registered consecutive year 2015-2016:54 × 2 yr period & 108 data \\
\hline State Enterprise: $19 \times 2$ th period & $(38)$ data \\
\hline Number of samples taken: 35 companies $\times 2$ yr period & $\mathbf{7 0 ~ d a t a}$ \\
\hline
\end{tabular}

Source: Data processed

\subsection{Operational variables}

1. Proportion of independent commissioners

Percentage of the number of independent commissioners to total board of commissioners

2. Intitutional ownership

Percentage of institutional ownership in the company's share structure.

3. Proportion of board of commissioners with accounting or business skills

Percentage of the number of boards of commissioners who have accounting or business skills to the total board of commissioners 
4. Proportion of audit committees with accounting or business skills

Percentage of the number of boards of commissioners who have accounting or business skills to the total board of commissioners

5. Frequency of board of commissioners meeting

The average percentage of attendance to total board of commissioners

6 . Frequency of board of commissioners meeting

The average percentage of attendance rate against the total number of audit committee meetings

7. Proportion of independent audit committee

Percentage of the number of independent commissioners to total board of commissioners

8. Voluntary Disclosure

Table 2. Valuation of voluntary disclosure will be obtained by scoring method, scoring for each criteria that has been determined

\begin{tabular}{|c|c|}
\hline tary disclos & \\
\hline $\begin{array}{l}\text { 1. Description of principal products/services-Market } \\
\text { share }\end{array}$ & 15. Return on shareholders' securities \\
\hline 2. Forecast profit year $n+1$ (qualitative) & 16. Number of employees \\
\hline 3. Forecast profit year $n+1$ (quantitative) & 17. Cash Ratio - Current Ratio \\
\hline 4. Future cash at horizon 2 to 5 years & 18. Other financial ratios \\
\hline $\begin{array}{l}\text { 5. Description of the major factories, warehouses and } \\
\text { properties }\end{array}$ & 19. Discussion on past industry tendencies \\
\hline $\begin{array}{l}\text { 6. Biographical Profile of Directors and Officers } \\
\text { (responsibilities, experience, courses) }\end{array}$ & 20. Discussion on future industry tendencies \\
\hline 7. General objectives of the firm - Missions & 21. Position and competitive environment \\
\hline $\begin{array}{l}\text { 8. Description of marketing network for final goods and } \\
\text { services }\end{array}$ & 22 Policy and financial objectives \\
\hline $\begin{array}{l}\text { 9. Main activity or affiliation of directors with other } \\
\text { organizations }\end{array}$ & $\begin{array}{l}\text { 23. Transactions, currency exchanges with } \\
\text { government }\end{array}$ \\
\hline 10. Information on the social responsibility of the firm & 24. Firm history \\
\hline 11. Historical share price - Trend & 25. Description of the organizational structure \\
\hline 12. Human Resources: Cost of training operations & 26. Developing new products / services \\
\hline 13. Value added statement & 27. Workers social report \\
\hline 14. Return on capital employed & 28. Advertising Expenditures: information and amount \\
\hline
\end{tabular}

Source: Hubert and Heger (2010)

\subsection{Analysis Method}

Data analysis method used is multiple linear regression analysis. Multiple regression analysis is a statistical technique used to predict the variation of dependent variables by heading more than one independent variable to the dependent variable simultaneously (source). In analyzing the data, the researcher used SPSS 22.00 program.

1. Descriptive Statistics Test

Descriptive statistics provide an overview or description of a data viewed from the mean (mean), standard deviation, variant, maximum and minimum.

2. Test the classical assumptions

a. Test Data Normality

Aims to test whether in the regression model, the confounding variable has a nornal distribution

b. Heteroscedasticity Test

Aims to see the data variance, whether homogeneous or heterogeneous

c. Multicollinearity Test

Aims to see whether or not a perfect relationship exists between independent variables, because in the classical assumption this should not happen

d. Autocorrelation Test 
Aims to test whether in the linear regression model there is a correlation between the confounding error in period $t$ with the intruder error in the previous $t-1$ period

\subsection{Hypothesis Testing}

a. Coefficient Determination Test (R2)

Measures the extent of the ability to explain variations of dependent variables

b. Simultaneous Significant Testing (Test Statistic F)

Indicates whether all independent or independent variables included in the model have a codependent effect on the dependent/dependent variable

c. Partial Sigification Test (Test Statistic $t$ )

Indicate how far the influence of an individual explanatory or independent variable in explaining the variation of the dependent variable.

\subsection{Test Multiple Linear Regression Analysis}

To determine the significant proportion of independent variables:

$y=\beta 0+\beta 1 X 1+\beta 2 X 2+\beta 3 X 3+\beta 4 X 4+\beta 5 X 5+\beta 6 X 6+\beta 7 X 7+\varepsilon$

Where:

$\mathrm{y}=$ Voluntary disclosure;

$\beta 0=$ Constants;

$\beta 1-7=$ coefficient of independent variable, if positive $\beta$ value there will be an increase of variable dependent $(Y)$, whereas if the negative $\beta$ value will decrease the dependent variable $(Y)$;

$\mathrm{X} 1$ = Proportion of independent commissioners;

$\mathrm{X} 2$ = Institutional Ownership;

$\mathrm{X} 3$ = the proportion of board of commissioners with accounting or business skills;

$\mathrm{X} 4$ = the proportion of audit committees with accounting or business skills;

$\mathrm{X} 5$ = frequency of board of commissioners meeting;

$X 6$ = frequency of audit committee meeting;

X7 = Proportion of independent audit committee;

$\varepsilon=$ default error.

\section{Results and discussions}

\subsection{Results}

1. Test statistic description

Descriptive statistical analysis is used to define descriptive data, where this analysis provides an overview of the maximum deviation, minimum, mean and standard. The following is the result of descriptive statistical analysis:

Table 3. Descriptive Test Result

Descriptive Statistics
\begin{tabular}{|c|c|c|c|c|c|}
\hline & $\mathrm{N}$ & Minimum & Maximum & Mean & Std. Deviation \\
\hline $\mathrm{x} 1$ & 70 & .33 & .80 & .4436 & .11726 \\
$\mathrm{x} 2$ & 70 & 25.85 & 85.00 & 57.1876 & 15.27465 \\
$\mathrm{x} 3$ & 70 & .11 & .60 & .3033 & .13355 \\
x4 & 70 & .33 & 1.00 & .5305 & .19698 \\
x5 & 70 & .63 & 1.00 & .9087 & .10238 \\
x6 & 70 & .67 & 1.00 & .9557 & .07461 \\
x7 & 70 & .20 & .67 & .3462 & .08361 \\
disclosure & 70 & .54 & .93 & .7673 & .09156 \\
Valid N (listwise) & 70 & & & & \\
\hline
\end{tabular}

Source: Process data: SPSS.22

1. The independent commissioner $(x 1)$ has the lowest value of 0.3 and the maximum value of 0.8 with an average of 0.44 and the standard deviation of 0.11 . This means that the entire company under 
study has been in accordance with the provisions contained in the POJK 33 and the Decree of the Board of Directors of PT Bursa Efek Indonesia. Kep-00001/BEl/01-2014 dated January 20, 2014 on Amendment to Regulation no. I-A on Stock and Equity Securities Listing In addition to Shares Issued by Listed Company ("BEI Regulation No. I-A"), wherein a public company must have an Independent Commissioner of at least $30 \%$ of the total members of the Board of Commissioners.

2. The institutional ownership (x2) has the lowest value of $25.85 \%$, namely Jababeka.co (KIJA) and the highest value of $85 \%$ by Unilever (UNVR). While the average shareholding of the company for 100 indexed companies by the institutional compass is $57.18 \%$ of the total outstanding shares.

3. The proportion of board of commissioners with accounting or business skills $(x 3)$ has the lowest value of 0.11 and a maximum value of 0.6 with an average of 0.30 . This means that the entire company under study has fulfilled the requirements of members of the board of commissioners have at least 1 person competence in accounting and business.

4. The proportion of audit committees with accounting or business skills (x4) has the lowest value of 0.33 and a maximum value of 1 with an average of 0.53 . This means the entire company under study has met the requirements of audit committee members have at least 1 person competence in the field of accounting and business.

5. The frequency of board of commissioners meeting $(x 5)$ has the lowest value of 0.67 and the maximum value of 1 with an average of 0.95 . This means that as a whole the company under study has fulfilled the Company's Articles of Association, the board of commissioners meeting shall meet at least once in two months.

6. The frequency of Audit Committee meetings (x6) has the lowest value of 0.63 and a maximum value of 1 with an average of 0.90 . This means that in whole the company under study has to meet the requirements of the Company's Articles of Association, the audit committee meeting shall convene meetings at least once every three (3) months.

7. The independent audit committee ( $x 7)$ has the lowest value of 0.2 and a maximum value of 0.67 with an average of 0.34 . This means that the entire company under study is in compliance with the provisions in which a public company must have an audit committee member of at least 1 person out of the total members of the audit committee.

8. Disclosure indicates that the average voluntary disclosure in the annual report is $76.73 \%$. This value indicates that the company indexed 100 compasses on average can meet 21 items of 28 voluntary disclosure items. The lowest level of voluntary disclosure was carried out by Tower Bersama Group (TBIG) with a disclosure rate of $54 \%$. While the highest voluntary disclosure is done by Matahari dept store (LPPF) with disclosure rate of $93 \%$.

\section{Classic Assumption Test}

a. Normality test

Normality test aims to test whether in the regression model, residual variables have a normal distribution.

Table4. Normality Test Results

One-Sample Kolmogorov-Smirnov Test

\begin{tabular}{|c|c|c|}
\hline & & Unstandardized Residual \\
\hline $\mathrm{N}$ & & 70 \\
\hline \multirow[t]{2}{*}{ Normal Parameters ${ }^{\mathrm{a}, \mathrm{b}}$} & Mean & .0000000 \\
\hline & Std. Deviation & .08056842 \\
\hline \multirow[t]{3}{*}{ Most Extreme Differences } & Absolute & .053 \\
\hline & Positive & .053 \\
\hline & Negative & -.049 \\
\hline Test Statistic & & .053 \\
\hline Asymp. Sig. (2-tailed) & & $.200^{c, d}$ \\
\hline
\end{tabular}

a. Test distribution is Normal.

b. Calculated from data.

c. Lilliefors Significance Correction.

d. This is a lower bound of the true significance. 
The Kolmogorov-Smirnov test shows that residual values are normally distributed; Kolmogorov Smirnov's statistical value obtained has a significant value greater than 0.05 of 0.200 where the value according to the data distribution criteria is normal.

\section{b. Multicollinearity Test}

Table 5. Multicollinearity Test Results

Coefficients $^{\mathrm{a}}$

\begin{tabular}{|ll|l|l|}
\hline \multirow{2}{*}{ Model } & \multicolumn{2}{c|}{ Collinearity Statistics } \\
\cline { 2 - 4 } & (Constant) & & VIF \\
\hline 1 & x1 & .915 & 1.093 \\
& x2 & .924 & 1.083 \\
& x3 & .860 & 1.163 \\
& x4 & .907 & 1.103 \\
& x5 & .923 & 1.084 \\
& x6 & .935 & 1.069 \\
& x7 & .922 & 1.084 \\
\hline
\end{tabular}

a. Dependent Variable: disclosure

From table 4 it shows that no independent variable has a tolerance value less than 0.10 and no independent variable has a VIF value greater than 10 . It is concluded that there is no multicolonicity among independent variables in the regression model.

\section{c. Heterocedasticity Test}

Heteroskedasticity test was conducted to determine whether in the regression model there was a variant inequality. Heteroskedasticity test can be done in several ways, namely scaterplot test, glesjer test, park test and spearman test. Based on the results of scaterplot testing obtained this study there is no heterokedastisitas.

\section{d. Autocorrelation Test}

Table 6. Autocorrelation Test Results

Model Summary ${ }^{b}$

\begin{tabular}{|c|c|}
\hline Model & Durbin-Watson \\
\hline 1 & 1.762 \\
\hline
\end{tabular}

a. Predictors: (Constant), x7, x4, x2, x1, x6, x5, x3

b. Dependent Variable: disclosure

Based on Table 6 the variables studied have a DW value of 1.762 with the amount of data $(n)=70$ and the number of free variables $(\mathrm{k})=7$ and $\alpha=5 \%$ obtained the number $\mathrm{dl}=1.4012$ and $\mathrm{du}=1.8375$. Test results produce baha by using Watbin durbin test is not free from autocorrelation, therefore to improve it is done Run Test test to produce more definitive conclusion.

Table 7. Test Run Test Results

Runs Test

\begin{tabular}{|l|c|}
\hline & Unstandardized Residual \\
\hline Test Value & .00091 \\
Cases $<$ Test Value & 35 \\
Cases >= Test Value & 35 \\
Total Cases & 70 \\
Number of Runs & 34 \\
Z & -.482 \\
Asymp. Sig. (2-tailed) & .630 \\
\hline
\end{tabular}

a. Median 
From the test run test results indicate that the value of Asymp.sign (2-tailed) $>0.05$ which means the null hypothesis failed to be rejected, thus, the data used is quite random so there is no problem autokorelasi on the data tested.

Hypothesis Testing

a. Determination test (R2)

Table 8. Determinant Test Results

Model Summary

\begin{tabular}{|c|c|c|c|c|c|}
\hline Model & $\mathrm{R}$ & $\mathrm{R}$ Square & Adjusted R Square & Std. Error of the Estimate & Durbin-Watson \\
\hline 1 & $.475^{\mathrm{a}}$ & .226 & .138 & .08500 & 1.762 \\
\hline
\end{tabular}

a. Predictors: (Constant), x7, x4, x2, x1, x6, x5, x3

b. Dependent Variable: disclosure

Table 8 shows that the value of Adjusted R2 is 0.138 . This means that the effect of independent proportion independent of independent commissioners, institutional ownership, commissioner competence, audit committee competence, board of commissioners meeting, audit committee meeting and proportion of independent audit committee to profit persistence is $13,8 \%$, while the rest equal to $86,2 \% \%$ influenced by other factors.

\section{b. Simultaneous Test (F)}

Table 9. Significant Significant Test Results F

ANOVA $^{\mathrm{a}}$

\begin{tabular}{|ll|c|c|c|c|c|}
\hline & Model & Sum of Squares & $\mathrm{df}$ & Mean Square & $\mathrm{F}$ & Sig. \\
\hline 1 & Regression & .131 & 7 & .019 & 2.581 & $.021^{\mathrm{b}}$ \\
& Residual & .448 & 62 & .007 & & \\
& Total & .578 & 69 & & & \\
\hline
\end{tabular}

a. Dependent Variable: disclosure

b. Predictors: (Constant), x7, x4, x2, x1, x6, x5, x3

Based on the results of statistical tests $\mathrm{F}$ in Table 9 above can be seen that together independent variables have a significant influence on the dependent variable. This can be proven from the value of $F$ arithmetic of 2.581 and $F$ table value of 2.14 which means $F$ arithmetic $>F$ table, with a significant level of 0.021 smaller than the significant level of 0.05 .

c. Partial Test (t)

Table 10. Partial Test Results ( $\mathrm{t}$ - test)

Coefficients $^{\mathrm{a}}$

\begin{tabular}{|c|c|c|c|c|c|c|}
\hline & \multirow{2}{*}{ Model } & \multicolumn{2}{|c|}{ Unstandardized Coefficients } & \multirow{2}{*}{$\begin{array}{c}\text { Standardized Coefficients } \\
\text { Beta }\end{array}$} & \multirow{2}{*}{$\mathrm{t}$} & \multirow{2}{*}{ Sig. } \\
\hline & & B & Std. Error & & & \\
\hline \multirow[t]{8}{*}{1} & (Constant) & 1.098 & .166 & & 6.632 & .000 \\
\hline & $\mathrm{x} 1$ & -.082 & .091 & -.104 & -.894 & .375 \\
\hline & $x 2$ & .002 & .001 & .319 & 2.744 & .008 \\
\hline & $x 3$ & -.034 & .083 & -.050 & -.412 & .682 \\
\hline & $x 4$ & -.111 & .055 & -.240 & -2.042 & .045 \\
\hline & $x 5$ & -.228 & .104 & -.254 & -2.187 & .033 \\
\hline & $x 6$ & -.185 & .142 & -.151 & -1.306 & .196 \\
\hline & $x 7$ & .143 & .127 & .131 & 1.123 & .266 \\
\hline
\end{tabular}

a. Dependent Variable: disclosure

Based on Table 10 above shows the value of $t$ arithmetic for each independent variable, as follows:

a. The first hypothesis states that the Proportion of Independent Board of Commissioners (X1) has a significant influence on Voluntary Disclosure. The result of $t$ test in Table 10 shows that $\mathrm{H} 1$ has significant 
value $>0.05$ that is 0.375 with value $t-0.894$. Thus the increase or decrease in the percentage of Proportion of Independent Commissioners does not affect the level of Voluntary Disclosure, so the first hypothesis $(\mathrm{H} 1)$ is rejected.

b. The first hypothesis states that Institutional Ownership (X2) has a significant effect on voluntary disclosure. Result of $\mathrm{t}$ test in table 10 shows that $\mathrm{H} 2$ has significant value $<0,05$ that is 0,008 with $\mathrm{t}$ value 2,744 . Thus the increase in percentage of institutional ownership will affect the level of corporate voluntary disclosure, so the second hypothesis $(\mathrm{H} 2)$ is accepted.

c. The third hypothesis states that the proportion of boards of commissioners with accounting or business ability (X3) has a significant influence on voluntary disclosure. Result of $t$ test in table 10 shows that $\mathrm{H} 3$ has significant value $>0.05$ that is 0.682 with value $t-0.412$. Thus the rise or fall of the proportion of the board of commissioners having accounting or business skills does not affect the company's voluntary disclosure, so the third hypothesis $(\mathrm{H} 3)$ is rejected.

d. The fourth hypothesis states that the proportion of audit committees with accounting or business skills (X4) has a significant influence on voluntary disclosure. Result of $t$ test in table 10 shows that $\mathrm{H} 3$ has significant value $<0,05$ which is 0,045 with value $t-2.042$. Thus the percentage increase or decrease The proportion of audit committees with accounting or business skills will affect the level of voluntary disclosure, the fourth hypothesis $(\mathrm{H} 4)$ is rejected.

e. The fifth hypothesis states that the frequency of meetings of the board of commissioners (X5) has a significant influence on voluntary disclosure. The result of t test on table 10 indicates that H5 has significant value $<0,05$ which is 0,033 with value $t-2.187$. So the rise or fall of the percentage of the board of commissioners' meeting will affect the level of voluntary disclosure, so the fifth hypothesis (H5) is rejected.

$\mathrm{f}$. The sixth hypothesis states the frequency of audit committee meetings (X6) has a significant effect on voluntary disclosure. Result of $\mathrm{t}$ test in table 10 shows that $\mathrm{H} 6$ has significant value $>0,05$ is 0,196 with value $t-1.306$. thus the increase or decrease in the percentage of the audit committee meeting does not affect the level of voluntary disclosure, so the fifth hypothesis (H6) is rejected.

g. The seventh hypothesis states that the proportion of independent audit committees (X7) has a significant influence on Voluntary Disclosure. The result of $\mathrm{t}$ test in Table 10 shows that $\mathrm{H} 1$ has significant value $>0,05$ that is 0,266 with value of $t 1,123$. Thus the percentage increase or decrease The proportion of the Independent audit committee does not affect the level of Voluntary Disclosure, so the seventh hypothesis $(\mathrm{H} 7)$ is rejected.

\section{Multiple regression analysis}

Based on table 10, the regression equation can be obtained as follows: $y=\beta 0+\beta 1 X 1+\beta 2 X 2+\beta 3 X 3+\beta 4 X 4+\beta 5 X 5+\beta 6 X 6+\beta 7 X 7+\varepsilon$ $y=1,098-0,82 X 1+0,002 X 2-0,412 X 3-2,042 X 4-2,187 X 5-1,306 X 6+1,123 X 7+\varepsilon$

\subsection{Discussions}

\section{Effect of Proportion of Independent Commissioners on Voluntary Disclosure}

The result of the hypothesis test shows that the proportion of independent commissioners has no effect on voluntary disclosure. It can be argued that the large number of independent commissioners does not provide effectiveness in the policy of the directors to disclose more voluntary information, with the number of independent members of the board of commissioners being more difficult to perform because of the diversity of opinion. Another factor is caused the board of commissioners only works for half the time, which means that the independent board member is not only an independent board of directors for one company only, but more than one company. This has led to independent board members to have difficulty understanding the complexities of the company's business operations so as to have less influence in influencing the decision-making process. This research is in line with Ayu (2013), Yudika (2015) and fitri (2017), but contrary to the research of yaseen (2013) and Sabri (2013) which in his research concluded that independent commissioners effectively determine decisions and monitor management for protecting the interests of shareholders in disclosing company information. 


\section{The Effect of Institutional Ownership on Voluntary Disclosure}

The hypothesis test results show that the proportion of institutional ownership has a positive effect on voluntary disclosure. Institutional ownership is the right of ownership of an enterprise owned by an institutional investor, thus high supervision by the outside (institution) of management requires the company to make voluntary disclosures widely. This is because the financial statements are important sources of information for investors so that it can be seen planning and evaluation company. The dominant voice in institutional share ownership can be an input to managers in disclosing the voluntary information needed by shareholders as part of the transparency of financial statements. This study is in line with Doaa et al. (2017) but is not in line with godeliva (2015).

\section{The effect of proportion of board of commissioners with accounting or business ability}

Result of hypothesis test show proportion of board of commissioner having accountancy or business ability influence to voluntary disclosure. In accordance with the 2006 Indonesia GCG Guidelines on the capacity and integrity of the members of the board of commissioners stating that the members of the board of commissioners must have a requirement of ability and integrity so that the implementation of supervisory functions and advice for the interests of the company can be implemented properly. Therefore, more board of commissioners who have the ability to account or business higher the level of corporate voluntary disclosure. However, this study produces a negative value of $t$ count, so it can be said that increasing the number of boards of commissioners who have accounting or business ability does not always increase the amount of voluntary disclosure of the company. With a large number of boards of commissioners familiar with accounting or business will increase the level of alertness and prudence of the board of commissioners in disclosing something that would limit the voluntary disclosure expressed by the company. This research is in line with Randy (2015) and Ula (2015).

4. The effect of audit committee proportions that have accounting or business skills

Hypothesis test results show the proportion of audit committees that have accounting or business ability effect the voluntary disclosure. Audit committees that understand the disclosure process will identify suspicious matters relating to disclosure and may minimize disclosure restrictions because the audit committee alerts the issues that the company should disclose. The Capital Market and Financial Institution Supervisory Agency (BapepamLK) in 2012 issued a requirement on audit committee membership that must have at least one member with educational background and accounting or business skills. This is done because having accounting or business skills will provide better knowledge and reporting quality so as to increase the level of corporate disclosure. However, in this study obtained a negative value of $t$ count, so it can indicating that the large proportion of audit committees that have accounting or business skills do not always increase the number of voluntary disclosure companies. The large number of audit committees familiar with accounting or business will increase the alertness and prudence of audit committees in disclosing something that would limit the voluntary disclosure expressed by the company. The results of this study are in line with Ken et al (2010) and Ula (2015).

\section{The effect of frequency of board meetings on voluntary disclosure}

The results of the Hypothesis test shows that the number of board of commissioners' meetings has no effect on voluntary disclosure. FCGI (2001) explains that the board of commissioners meeting is a communication and coordination medium among management. From the perspective of agency theory, the frequency of meetings can be viewed as the time proxies used by the board to carry out the tasks and levels of their monitoring activities (Laksamana, 2008). The meeting will address issues regarding the company's direction and strategy, the policy evaluation that has been taken or carried out by the management, and address the conflict of interest issues. However, in the results of this study can be said the frequency of meetings of the board of commissioners less effective run in the supervision of voluntary disclosure. This result is not in line with Ula (2015) and Gantyowati with the Dewi (2011) which concludes that the increasing number of board meetings, the level of supervision on the performance of managers of voluntary disclosure will also increase. With increased supervision will increase the level of voluntary disclosure.

\section{The effect of frequency of audit committee meeting on voluntary disclosure}

The result of the hypothesis test shows that the frequency of audit committee meetings has no effect on voluntary disclosure. In accordance with the requirements of Bapepam-LK (2012) in the Decision of the 
Chairman of the Capital Market and Financial Institution Supervisory Agency Number: KEP643 / BL / 2012 stating that the audit committee meeting is at least equal to the minimum requirement of the board of commissioners meeting stipulated in the articles of association. Thus high Frenkuensi meetings are expected to increase the level of coordination, level of supervision, and control and impact on increasing levels of disclosure made by the company. However, in this study, the frequency of audit committee meetings is less effective. These results are in line with Ula (2015) and Ayu (2013) which infer the inefficiency of meetings conducted by the audit committee.

\section{The effect of the proportion of independent audit committees on voluntary disclosure}

The results of the Hypothesis test shows that the proportion of independent audit committee has no effect on voluntary disclosure. The audit committee has an important role in ensuring the quality of financial reporting, reviewing, and assessing the internal control system and monitoring the relationship between management and external auditors (NACD, 2000). Increased surveillance will minimize the possibility of manipulation and restrictions in disclosure so that the company's voluntary disclosure may increase. However, in this study obtained the number of independent audit committees did not play a good enough role in providing adequate and quality information on voluntary disclosure in the financial statements. This result is in line with Yaseen (2012) and Ula (2015) which concludes that the large number of independent audit committees does not guarantee the quality of financial statements in disclosing voluntary information.

\section{Conclusions}

Based on the results of hypothesis testing it can be drawn a conclusion as follows:

a. The proportion of independent commissioners has no effect on voluntary disclosure. The number of independent members of the board of commissioners will be increasingly difficult to perform because of the diversity of opinions.

b. The proportion of institutional ownership affects voluntary disclosure. Thereby high supervision of the outside (institution) of management requires the company to make voluntary disclosures widely.

c. The proportion of boards of commissioners possessing accounting or business skills has an effect on voluntary disclosure. However, the negative number on the value of $t$ counts, it can be said that the increasing number of boards of commissioners who have accounting or business ability does not necessarily increase the number of voluntary corporate disclosures.

d. The proportion of auditing committees with accounting or business skills has an effect on voluntary disclosure. However, the negative number on the value of $t$ count, it can be said that increasing the number of audit committees that have accounting or business skills do not always increase the amount of voluntary disclosure of the company.

e. The frequency of board of commissioners' meetings has no effect on voluntary disclosure. Thus, the board of commissioners meetings is less effective in discussing and overseeing the company's voluntary disclosure.

f. The frequency of audit committee meetings has no effect on voluntary disclosure. Thus, the audit committee meeting is less effective or does not discuss things that the company's voluntary disclosure on the financial statements but rather to monitor the company's internal control system only.

g. The proportion of independent audit committees has no effect on voluntary disclosure. Thus an independent audit committee does not play a good enough role in providing adequate and quality information on voluntary disclosure to financial statements.

\section{Limitations of study}

Based on the results of research and conclusion, this study has several limitations, namely:

a. This research is only limited using a sample of 100 compass indexed companies listed on the Stock Exchange for companies outside the financial sector and government-owned companies, so that the research results are less representative of all companies in Indonesia.

b. This study in determining volunteer items is limited to media that only uses the company's annual report and there is an element of subjectivity in determining the voluntary disclosure index

c. corporate governance variables do not cover all proxies and are still limited. 


\section{Suggestions}

For further research it is advisable to:

a. Add samples by entering all types of industry companies.

b. Expand reporting media such as corporate website, print media, or other media.

c. Add other corporate governance variables.

d. Due to the determinant on the result obtained $13.8 \%$ it is advisable to add other variables such as financial ratios

e. Further research is suggested to use more current voluntary disclosure items that apply to go public companies in Indonesia.

\section{References}

1. Ali, U. (2011). Firm characteristics and voluntary disclosure of graphs in annual reports of Turkish listed companies. African Journal of Business Management Vol. 5 (17).

2. Ali, U., Merve, K., \& Nizamettin, B. (2013). Association between firm characteristics and corporate voluntary disclosure: Evidence from Turkish listed companies. OmniaScience, Intangible Capital Vol 9 (4).

3. Akhtaruddin, M., Alama, M., Hossain. \& Lee, Y. (2009). Corporate Governance and Voluntary Disclosure in Corporate Annual Reports of Malaysian Listed Firms. Journal of Applied Management Accounting Research. Vol. 7.(1)

4. Ayu, K.A. (2013). Influence of Ownership Structure and Composition of Independent Commissioners against the Voluntary Disclosure Level. University of Gajah Mada.

5. Barnhart, S. W., \& Rosenstein, D.S. (1998). Board composition, managerial ownership, and firm performance: An empirical analysis. The Financial Review, 33(4).

6. Bapepam, L.K. (2012). Decision of the Chairman of the Capital Market and Financial Institution Supervisory Agency Number: KEP643/BL/2012.

7. Dwi, P. O. (2016). Determinan Voluntary Disclosure Level: Empirical Studies at a Manufacturing Company listed on the Indonesia Stock Exchange. Akuntabilitas : Jurnal Ilmu Akuntansi . Vol. 9. (2).

8. Doaa El-Diftar, E. J., M. Ragheb, \& Soliman, M. (2017). Institutional investors and voluntary disclosure and transparency: the case of Egypt, Corporate Governance: The International Journal of Business in Society. Vol. 17 (1).

9. Fawzi, A. S. (2016). Corporate Governance Mechanisms and Voluntary Disclosure Compliance: The Case of Banks in Jordan. International Journal of Academic Research in Accounting, Finance and Management Sciences Vol. 4 (2), pp.369-384. IJARAFMS E-ISSN: 2225-8329, P-ISSN: 2308-0337.

10.Fabio, C., \& Mandanici, F. (2015). Voluntary Disclosure and Capital Market Insights from Italian Industrial Listed Companies. International Journal of Business and Social Science, Vol. 6 (9).

11.Fitri, I.,\& Ayu, D. (2017). Institutional Ownership and Its Characteristics Effect on Discussion of Sukarela in Annual Report (Empirical Study of Manufacturing Companies Listed on BEI Period 2013 - 2015. Research Journal of Finance and Accounting. ISSN 2222-2847. Vol. 8 No.12.

12.FCGI. (2001). Corporate Governance: tata kelola perusahaan, third edition. Jakarta.

13.Godeliva, P., \& Ika Nugroho, P. (2015). Influence of Corporate Mechanism Governance and Financial Distress Conditions against Extent of Disclosure Voluntary in Company Annual Report. 4th Economics \& Business Research Festival. 4 (1).

14.Gantyowati, E. \& Nugraheni, R.L. (2014). The Impact of Financial Distress Status and Corporate Governance Structures on the Level of Voluntary Disclosure within Annual Reports of Firms. Journal of Modern Accounting and Auditing. 10(4).

15.George, M., \& Jeffrey, Henderson, J. (2013). Voluntary Disclosure of Intellectual Assets and Intellectual Liabilities: Impact on Financial Performance in Publicly Listed Firms in the United Arab Emirates. Electronic Journal of Knowledge Management, 11 (4).

16.Ghozali, I. (2013). Aplikasi Analisis Multivariate dengan Program SPSS. Seventh edition. Semarang : Badan Penerbit Universitas. 
17. Heger, G., \& de la bruslerie, H. (2010). Voluntary Financial Disclosure, Introduction of IFRS and the Setting of a Communication Policy: an Empirical Test on SBF French Firms Using a Publication Score. Dauphine Rechershes en Management.

18. Haddad, A., \& Haitham, N. (2009). Voluntary disclosure and stock market liquidity: Evidence from the Jordanian capital. Int. J. Accounting, Auditing and Performance Evaluation, 5(3).

19.Ho, S.S.M., \& Kar Shun, W. (2001). A study of the relationship between corporate governance structures and the extent of voluntary disclosure. Journal of International Accounting Auditing \& Taxation. $10(2)$.

20.Jensen, M., \& Meckling, W.H. (1976). Theory of the Firm: Magerial Behavior, Agency Cost and Ownership Structure. Journal of Financial Economics, Vol 3.

21.Juniarti, \& Sentosa, A.A. (2009). The Influence of Good Corporate Governance, Voluntary Disclosure against Costs of Debt. Journal Accounting and finance, 11(2).

22.Jihene, F., \& Skanj, M. (2017). Audit Committee and Board Effectiveness against Voluntary Disclosure in the Pre and Post Enactment of the Tunisian Central Bank Circular n. 2011-06 of Good Governance Practices. International Research Journal of Finance and Economics. Issue 159.

23.Khan, I., Chand, V.P. \& Patel, A. (2012). The Impact Ownership Structure on Voluntary Corporate Disclosure in Annual Reports: Evidence from Fiji. Accounting and taxation, 5(1).

24.Laksamana, I. (2008). Corporate Board Governance and Voluntary Disclosure of Executive Compensation Practices. Contemporary Accounting Research, 25(4).

25.Nuryaman (2010). The effect of Characteristics of Commisioner Board, Industry Specialize Audit Firm on Earnings Management and voluntary disclosure: Evidence from Indonesia. The $3 \mathrm{rd}$ International Accounting Conference. Indonesia University.

26.Othman, R., Ishak, I.F., Arif, S.M.M., \& Aris, N.A. (2014). Influence of audit committee characteristics on voluntary ethics disclosure. Procedia - Social and Behavioral Sciences. Issue 145.

27.Randy, Y., \& Muid, D. (2015). The effect of financial distress and corporate governance on voluntary disclosure widely. Diponegoro Journal of accounting, 4(3).

28.Sabri, B. (2013). Corporate governance and voluntary disclosure in France. The journal of applied business research, 29(2).

29.Sehar, N., B., \& Tufail, S. (2013). Determinants of Voluntary Disclosure in Annual Report: A Case Study of Pakistan. Management and Administrative Sciences Review, 2(2).

30.Ula, R., \& Ratmono, D. (2015). The effect of corporate governance mechanisms on the annual report. Diponegoro Journal of accounting, 4(3).

31.Yunita, N. (2012). Effect of Corporate Governance on Voluntary Disclosure And Debt Costs. Journal of Accounting Students, 1(1).

32.Monks, R.A.G. \& Minow, N. (2004) Corporate Governance, 3rd edition. Oxford: Blackwell.

33.Nancy, Y. (2012). Pengaruh Corporate Governance Terhadap Voluntry Disclosure dan Biaya, Hutang. Jurnal Ilmiah Mahasiswa Akuntansi, 1(1).

34.Wiwik, U. (2006). Dampak Pengungkapan Sukarela dan Manajemen Laba terhadap Informasi Asimetri. Media Riset Akuntansi, Auditing \& Informasi, 6(1). 